\title{
Apical localization of ITPK1 enhances its ability to be a modifier gene product in a murine tracheal cell model of cystic fibrosis
}

\author{
Ling Yang ${ }^{1,2}$, Jeff Reece ${ }^{2}$, Sherif E. Gabriel ${ }^{3}$ and Stephen B. Shears ${ }^{1,2, *}$ \\ ${ }^{1}$ Inositol Signaling Section, and ${ }^{2}$ Laboratory of Signal Transduction, N.I.E.H.S. / N.I.H. / D.H.S.S., Research Triangle Park, NC 27709 , USA \\ ${ }^{3}$ Department of Pediatrics and Cystic Fibrosis/Pulmonary Research and Treatment Center, University of North Carolina at Chapel Hill, Chapel Hill, \\ NC 27599, USA \\ *Author for correspondence (email: shears@ niehs.nih.gov)
}

Accepted 14 December 2005

Journal of Cell Science 119, 1320-1328 Published by The Company of Biologists 2006 doi:10.1242/jcs.02836

\section{Summary}

A new aspect of research into the pathogenesis of cystic fibrosis (CF) is a genetics-based search for 'modifier genes' that may affect the severity of CF lung disease. Using an alternative, cell biological approach, we show that ITPK1 should be considered a modifier gene. ITPK1 synthesizes an intracellular signal, inositol $(3,4,5,6)$-tetrakisphosphate $\left[\operatorname{Ins}(3,4,5,6) P_{4}\right]$. A bio-activatable, cell-permeable analogue of Ins $(3,4,5,6) P_{4}$ inhibited $\mathrm{Ca}^{2+}$-dependent secretion of $\mathrm{Cl}^{-}$ from polarized monolayers of immortalized mouse tracheal epithelial cells (MTEs). Analysis by high-pressure liquid chromatography showed endogenous $\operatorname{Ins}(3,4,5,6) P_{4}$ levels in CF MTEs were approximately $60 \%$ below those in wildtype MTEs $(P<\mathbf{0 . 0 3})$. This adaptation, which improves purinergic activation of $\mathrm{Ca}^{2+}$-dependent $\mathrm{Cl}^{-}$secretion in $\mathrm{CF}$

MTEs, was exceptionally specific; there was no effect upon the cellular levels of all the other inositol phosphate signals. Real-time PCR provided the explanation: the level of ITPK1 expression in wild-type MTEs was twice as high as that in CF MTEs $(P<0.002)$. The biological impact of this differential gene expression is amplified by ITPK1 being concentrated at the apical membrane of MTEs, which we discovered following confocal immunofluorescence microscopy. Compartmentalization of $\operatorname{Ins}(3,4,5,6) P_{4}$ synthesis adjacent to its site of action will enhance its regulatory capacity.

Key words: ITPK1, Cystic fibrosis, inositol phosphates, CFTR, Secretion, Chloride channel

\section{Introduction}

Individuals that suffer from cystic fibrosis (CF) have an average life-span of just over 30 years, and almost all of them die from lung disease (Boucher, 2004). The pernicious nature of the disorder is due to the mutations in the cystic fibrosis transmembrane regulator (CFTR) that lead to a reduction in $\mathrm{Cl}^{-}$ secretion and enhanced $\mathrm{Na}^{+}$absorption across airway epithelia of CF patients (Boucher, 2004). These defects in ion transport perturb osmotic water movement leading to a reduction in the airway-surface-liquid volume, thereby disturbing the height and composition of the mucus and periciliary liquid layers (Boucher, 2004). The mucus layer contains a highly glycosylated and tangled network of mucin proteins that normally engulfs inhaled pathogens, and then helps to expel them from the host. In CF patients, the mucus layer thickens in response to defective salt and fluid transport, encouraging bacterial colonization and promoting an endobronchial inflammatory response that ultimately destroys the lung tissue (Boucher, 2004; Heijerman, 2005).

Cystic fibrosis is a monogenic disease, and the most common mutation is a deletion of phenylalanine at position $508(\Delta \mathrm{F} 508)$. Nevertheless, even in those patients in whom $\Delta \mathrm{F} 508$ is homozygous, there is considerable variability in the severity of CF-based lung disease that cannot be predicted purely from CFTR genotype of an individual (Merlo and Boyle, 2003; Boucher, 2004). This has led to a search for

epistatic genes, more recently termed 'modifier genes' (Boucher, 2004; Merlo and Boyle, 2003), that may either intensify or ameliorate the disease. An improved ability to predict phenotype from genotype, by expression analysis of genuine modifier genes, i.e. 'molecular profiling' (Stoughton and Friend, 2005), could offer new targets for more effective CF therapy earlier in life, before lung disease is irretrievably established (Boucher, 2004).

In the current study, we have deployed a cell biology approach to assess the possibility whether modifier gene products in $\mathrm{CF}$ include cell-signaling and accessory proteins that regulate the conductance of $\mathrm{Ca}^{2+}$-activated $\mathrm{Cl}^{-}$channels (CaCCs). We have focused in this area because $\mathrm{CaCCs}$ conduct $\mathrm{Cl}^{-}$ions across the plasma membrane independently of CFTR (Kidd and Thorn, 2000; Jentsch et al., 2002; Loewen and Forsyth, 2005). CaCCs can be activated by, for example, purinergic agonists that are released into the extracellular space following mechanical stimulation of cells by tidal air flow or by coughing (Lazarowski and Boucher, 2001; Tarran et al., 2005). These ligands bind to receptors on the luminal surface of airway epithelia, thereby initiating phospholipase C (PLC)dependent release of intracellular $\mathrm{Ca}^{2+}$, activating $\mathrm{CaCCs}$ (Boucher, 2004). This adaptive process is also the basis for at least one therapeutic approach to treat $\mathrm{CF}$ that is currently undergoing clinical trials; pharmacological upregulation of salt- and fluid-secretion by stimulating $\mathrm{CaCC}$ activity with a 
Fig. 1. Ins $(3,4,5,6) P_{4}$ inhibits $\mathrm{Ca}^{2+}$ dependent $\mathrm{Cl}^{-}$secretion across WT and CF MTE monolayers. (A-D) ISC across WT (blue traces) and CF (red traces) MTE monolayers was measured as described in Materials and Methods. Incubation time was set to zero at the point at which UTP $(100 \mu \mathrm{M})$ was added to the apical chamber. Where indicated, $\mathrm{Bt}_{2} \mathrm{Ins}(3,4,5,6) \mathrm{P}_{4} / \mathrm{PM}$ and $\mathrm{Bt}_{2} \operatorname{Ins}(1,4,5,6) \mathrm{P}_{4} / \mathrm{PM}$ were added to the apical chamber of the Ussing apparatus at a concentration of $50 \mu \mathrm{M}, 2$ hours prior to the addition of UTP. KN93 was added at a concentration of $5 \mu \mathrm{M}, 2$ hours prior to UTP addition.

Representative traces are shown in A-D. (E) Graphs show the average height of $\Delta \mathrm{I}_{\mathrm{SC}}$ peaks for the various experiments (mean \pm s.e.m. of 4-6 determinations). Numbers above each bar indicate its percentage value relative to vehicletreated cells within the same group [either WT (blue bars) or CF (red bars)].
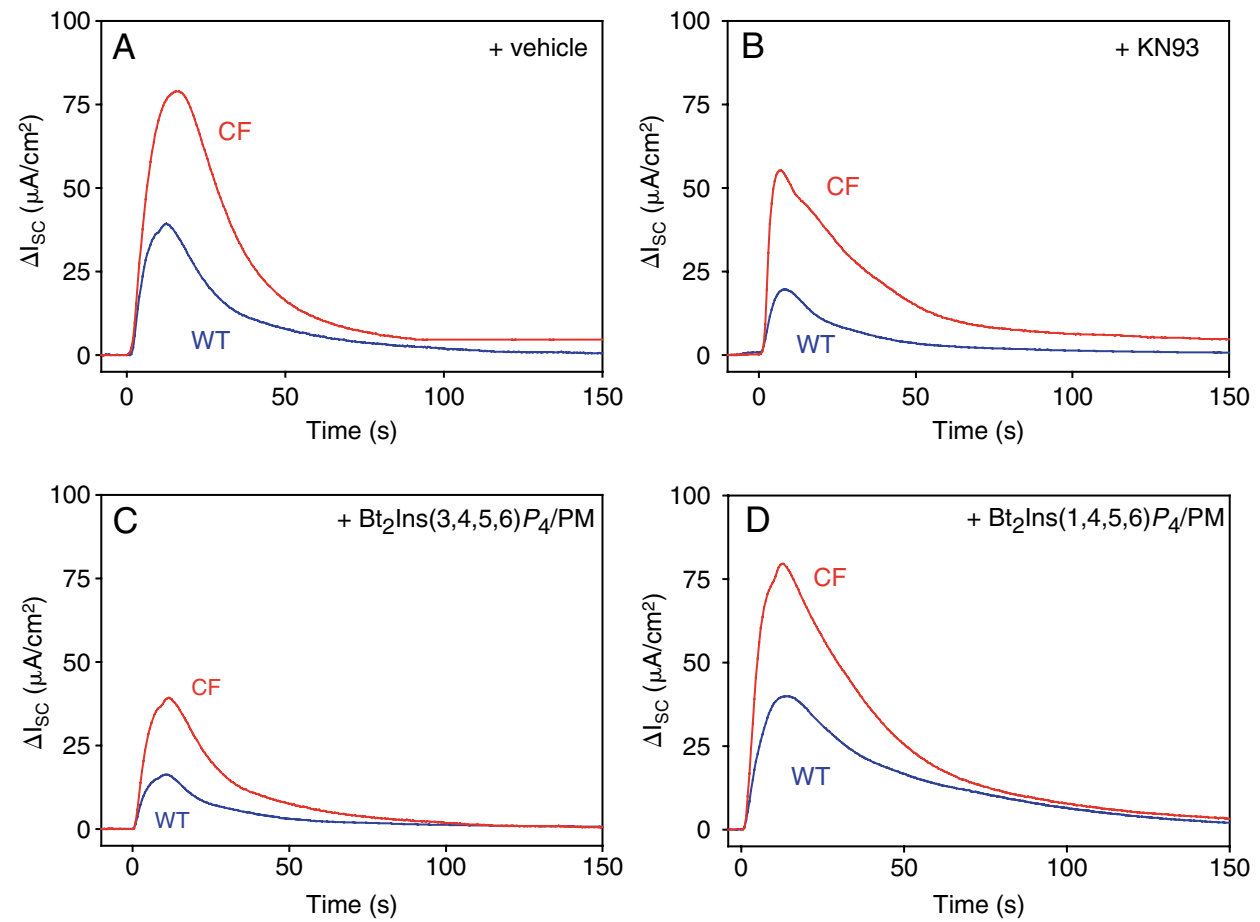

metabolically stable purinergic agonist (Boucher, 2004; Deterding et al., 2005). However, we have hypothesized that the efficacy of this drug is constrained by the actions of one particular inositol phosphate, inositol $(3,4,5,6)$ tetrakisphosphate $\left[\operatorname{Ins}(3,4,5,6) P_{4}\right]$ (Ho and Shears, 2002). Ins $(3,4,5,6) P_{4}$ accumulates following the activation of PLC (Menniti et al., 1990; Carew et al., 2000) and has been shown to inhibit certain CaCCs (Ismailov et al., 1996; Xie et al., 1996; Carew et al., 2000; Ho et al., 2001). On the other hand, not all CaCCs are regulated by Ins $(3,4,5,6) P_{4}$ (Sasakawa et al., 1994; Ho and Shears, 2002) nor has it previously been demonstrated that airway epithelia use $\operatorname{Ins}(3,4,5,6) P_{4}$ to regulate $\mathrm{Cl}^{-}$ secretion.

Thus, our first goal in the current study was to determine whether Ins $(3,4,5,6) P_{4}$ can inhibit $\mathrm{Cl}^{-}$secretion in an airwayepithelial-cell model. For these experiments, we have used the immortalized wild-type (WT) and CF murine tracheal epithelial (MTE) cell lines described previously (Tarran et al., 2002). The selection of this model also enabled us to pursue earlier observations that are directly pertinent to our separate goal of identifying genes that influence the severity of the CF condition (see above): $\mathrm{CaCC}$ activity in receptor-activated $\mathrm{CF}$ MTEs is greater than that in WT MTEs (Tarran et al., 2002; Thomas et al., 2000). This upregulation of $\mathrm{CaCC}$ activity is also typical of the human CF condition (Clarke et al., 1994; Grubb et al., 1994; Paradiso et al., 2001; Ribeiro et al., 2005; Mall et al., 2003). In humans, this in part reflects an inflammation-dependent expansion of the apical network of the endoplasmic reticulum in response to chronic luminal airway infection, which increases the capacity of cellular $\mathrm{Ca}^{2+}$ stores (Ribeiro et al., 2005). However, this is an effect that is environmental rather than epistatic in origin. A different phenomenon was the basis for our interest in identifying potential modifier genes. Previous work indicated that, independent of the magnitude of PLC-initiated $\mathrm{Ca}^{2+}$ signals,

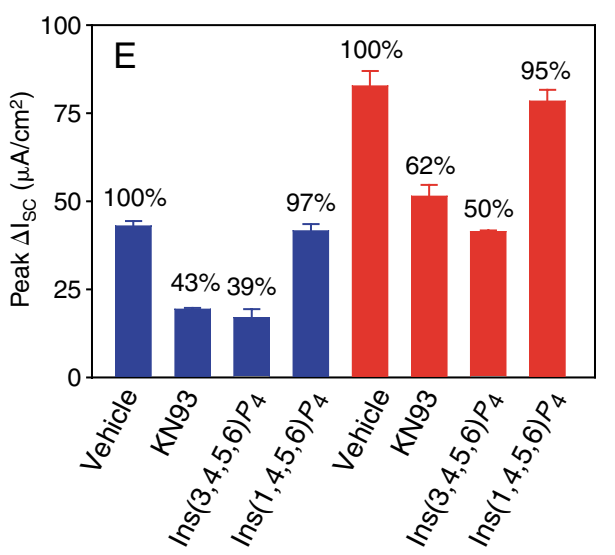

$\mathrm{Cl}^{-}$conductance via CaCCs was inherently higher in CF MTEs compared with WT MTEs (Tarran et al., 2002). The molecular basis for this particular effect has not previously been characterized. In this study we demonstrate that genetically based variability in the strength of the $\operatorname{Ins}(3,4,5,6) P_{4}$-signaling system can contribute to this elevated conductance of CaCCs in CF MTEs. Such an effect represents a demonstration that ITPKl is a potential modifier gene; variability in its degree of expression may contribute to the severity of the CF condition and may affect CF-drug efficacy.

\section{Results}

Ins $(3,4,5,6) P_{4}$ inhibits $\mathrm{Cl}^{-}$secretion from tracheal epithelial monolayers

Transepithelial $\mathrm{Cl}^{-}$secretion was measured as an increase in electrogenic ion transport $\left(\Delta \mathrm{I}_{\mathrm{SC}}\right)$ across a polarized monolayer from the basolateral to apical chambers of the Ussing apparatus (Fig. 1). In these experiments, we recorded the response to a maximally effective dose of UTP $(100 \mu \mathrm{M})$ (Tarran et al., 
2002). In WT MTEs (Fig. 1A, blue line), UTP quickly initiated a rapid rise in $I_{S C}$ that peaked after $20-25$ seconds. $I_{S C}$ then declined back to the baseline, by typically no more than 150 seconds after the addition of UTP (Fig. 1). The height of the peak was found to be directly proportional to total $\Delta \mathrm{I}_{\mathrm{SC}}$, calculated by integrating the area under the curve (data not shown). Verification that $\Delta \mathrm{I}_{\mathrm{SC}}$ solely represents changes in $\mathrm{Cl}^{-}$ secretion came from control experiments, in which $\mathrm{Cl}^{-}$in the bathing media was replaced by gluconate or when $\mathrm{Cl}^{-}$channels were pharmacologically blocked by 4,4'diisothiocyanatostilbene-2,2'-disulfonic acid (DIDS). Under such circumstances, UTP does not alter $\mathrm{I}_{\mathrm{SC}}$ (Thomas et al., 2000). Furthermore, addition of amiloride to the mucosal bathing solution did not affect $\mathrm{I}_{\mathrm{SC}}$ (data not shown) (see also Thomas et al., 2000), indicating that $\mathrm{Na}^{+}$conductance does not contribute to $\mathrm{I}_{\mathrm{SC}}$.

In previous studies (Thomas et al., 2000; Tarran et al., 2002), it was shown that UTP-dependent $\mathrm{Cl}^{-}$secretion was elevated in CF MTEs compared with WT cells. This result recapitulates a well-recognized observation that $\mathrm{CaCC}$ activity is upregulated in the $\mathrm{CF}$ condition, although the molecular basis for this effect is not well understood (Clarke et al., 1994; Grubb et al., 1994; Paradiso et al., 2001; Ribeiro et al., 2005; Mall et al., 2003). In agreement with this earlier work, we found that following the addition of UTP, $\Delta \mathrm{I}_{\mathrm{SC}}$ was about twofold greater in CF MTEs compared with WT MTEs (Fig. 1A,E).

Previous experiments have determined that airway epithelial $\mathrm{Cl}^{-}$channels can be regulated by both $\mathrm{Ca}^{2+}$ and by calmodulindependent protein kinase II (CaMKII) (Chao et al., 1994; Wagner et al., 1992; Chan et al., 1992; Fuller et al., 1994; Ismailov et al., 1996), but the relative importance of the two processes in regulating $\mathrm{Cl}^{-}$secretion in airway cells has so far not been determined. This issue is significant to the current study because it is the CaMKII-dependent process that is more potently inhibited by $\operatorname{Ins}(3,4,5,6) P_{4}$ (Ho et al., 2001; Ismailov et al., 1996). When cell-permeable KN93 was used to inhibit CaMKII, $\Delta \mathrm{I}_{\mathrm{SC}}$ was reduced by $57 \pm 1 \%$ in WT cells and by $38 \pm 4 \%$ in CF cells (Fig. 1B,E). Therefore, CaMKII contributes to a substantial proportion of transepithelial $\mathrm{Cl}^{-}$secretion in both cell types.

We next examined the effect of $\operatorname{Ins}(3,4,5,6) P_{4}$ on transepithelial $\mathrm{Cl}^{-}$secretion. We specifically elevated intracellular levels of $\operatorname{Ins}(3,4,5,6) P_{4}$ by treating the monolayer culture with a cell-permeable, bio-activatable analogue of this inositol phosphate (Vajanaphanich et al., 1994; Rudolf et al., 2003). This type of experiment has previously only been performed in two cell lines, in $\mathrm{T}_{84}$ colonic epithelia and CFPAC-1 pancreatic epithelia (Vajanaphanich et al., 1994; Carew et al., 2000). We were able to show that $50 \mu \mathrm{M} \mathrm{Bt} 2 \operatorname{Ins}(3,4,5,6) P_{4} / \mathrm{PM}$ (the analogue of Ins $\left.(3,4,5,6) P_{4}\right)$ inhibited $\Delta \mathrm{I}_{\mathrm{SC}}$ by $40-50 \%$ in both $\mathrm{CF}$ and WT MTEs (Fig. 1C,E). Restrictions on the availability of the cell-permeant inositol phosphate analogues prevented us from producing detailed dose-response relationships, but we did find that increases in analogue concentration (up to 150 $\mu \mathrm{M})$ did not further inhibit $\Delta \mathrm{I}_{\mathrm{SC}}$ (data not shown). Thus, we conclude that our routine experiments (Fig. 1) deploy a maximally effective dose of $\mathrm{Bt}_{2} \operatorname{Ins}(3,4,5,6) P_{4} / \mathrm{PM}$. The inactive stereoisomer $\mathrm{Bt}_{2} \operatorname{Ins}(1,4,5,6) P_{4} / \mathrm{PM}$ did not affect $\Delta \mathrm{I}_{\mathrm{SC}}$ (Fig. 1D,E).
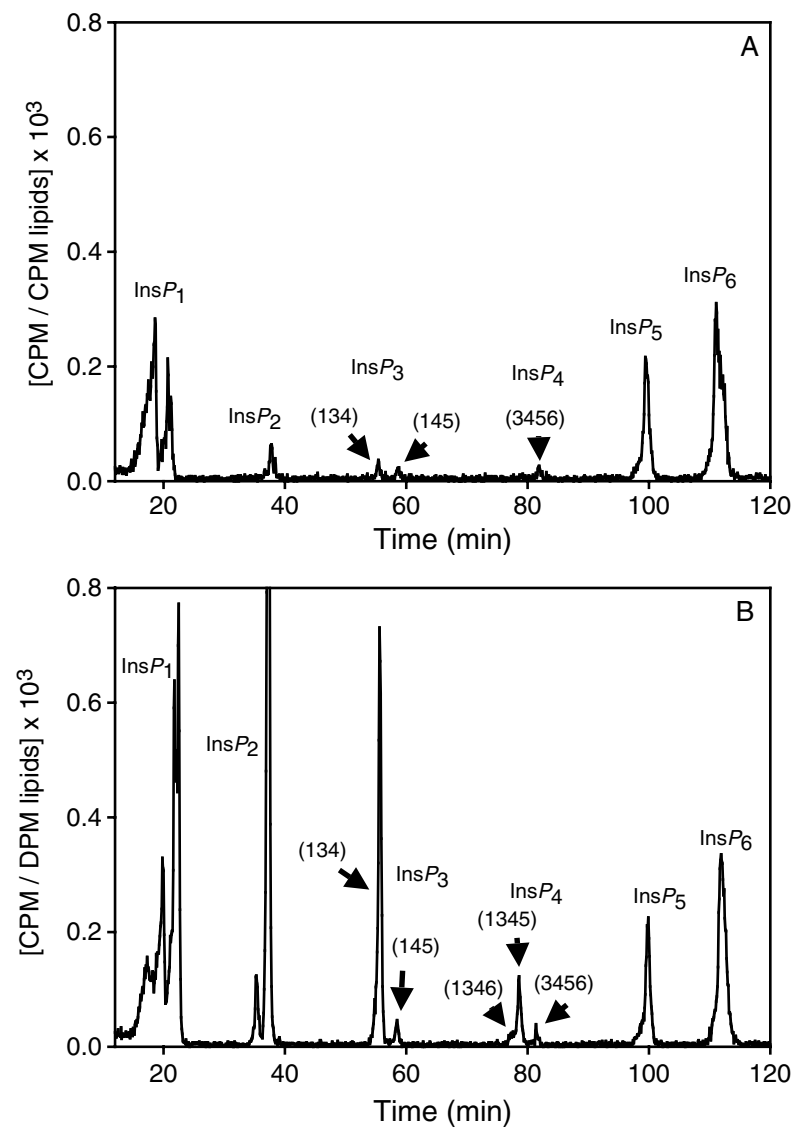

Fig. 2. Inositol-phosphate profile in MTEs. (A,B) Cells were labeled for 4 days with $\left[{ }^{3} \mathrm{H}\right]$ inositol. Cells were treated with either (A) vehicle or (B) $100 \mu \mathrm{M}$ UTP for 90 seconds and the inositol phosphate levels were determined by HPLC as described in Materials and Methods. A representative experiment is shown.

Inositol-phosphate levels in intact cells

We have used high performance liquid chromatography (HPLC) to analyze the inositol-phosphate profile in confluent MTEs during the same time-course as the transient peak of chloride secretion (see above). Resting cells contained low levels of $\operatorname{Ins} P_{1}, \operatorname{Ins} P_{2}, \operatorname{Ins} P_{3}$ and $\operatorname{Ins} P_{4}$ (Fig. 2A) that increased dramatically upon PLC activation by the addition of UTP (Fig. 2B). Total PLC activity in WT and CF MTEs is shown in Fig. 3 ; these data were obtained by summation of levels of Ins $(1,4,5) P_{3}$ and all of its downstream metabolites (see Carew et al., 2000). A bi-phasic stimulation of PLC was observed (Fig. 3). During the initial phase, which was completed within 30 seconds of agonist addition, there was a five- to six-fold increase in total inositol phosphates (Fig. 3). From 30 minutes onwards, levels of inositol phosphates continued to increase, but at a considerably slower rate (Fig. 3). Such an effect is attributable to receptor desensitization (Menniti et al., 1992). Both WT and CF cells showed a similar degree of PLC activation (Fig. 3). Levels of Ins $(1,4,5) P_{3}$, the intracellular $\mathrm{Ca}^{2+}$-mobilizing signal (Berridge et al., 2000), were also identical in both cell types (Fig. 4A). Phosphorylation of $\operatorname{Ins}(1,4,5) P_{3}$ by isomer-specific 3-kinases, resulting in Ins $(1,3,4,5) P_{4}$, has been argued to regulate $\mathrm{Ca}^{2+}$ entry into cells (Irvine, 1991). However, levels of Ins $(1,3,4,5) P_{4}$ (Fig. 4B), and 


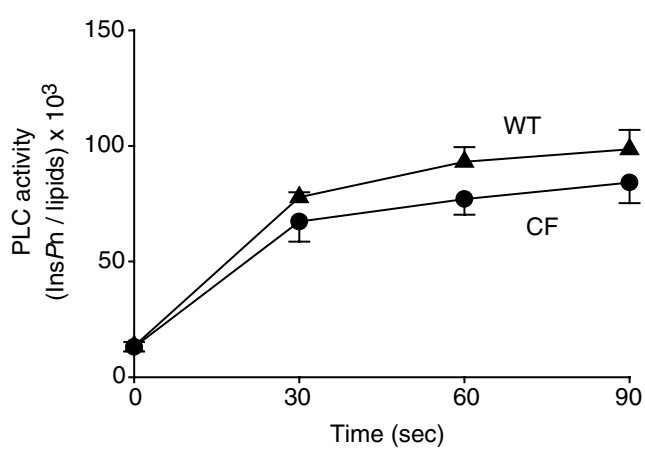

Fig. 3. PLC activity in MTEs activated with UTP. WT ( $\boldsymbol{\Delta})$ and CF (O) cells were labeled for 4 days with $\left[{ }^{3} \mathrm{H}\right]$ inositol. Cells were treated with vehicle (the zero time point) or UTP (for 30,60 or 90 seconds). Individual inositol phosphate levels were determined by HPLC as described in Materials and Methods. PLC activity is computed from the increase in $\operatorname{Ins} P_{1}+\operatorname{Ins} P_{2}+\operatorname{Ins} P_{3}+\operatorname{Ins} P_{4}$ but excluding Ins $(3,4,5,6) P_{4}$ (see Carew et al., 2000 for an explanation). Data represent mean \pm s.e.m. of five experiments.

its immediate metabolite, $\operatorname{Ins}(1,3,4) P_{3}$ (Fig. 4C) were also similar in both cell types. The data in Figs 3 and 4, therefore, show that there is no fundamental difference in the properties of the PLC signaling system between the CF and WT MTEs. Nevertheless, Ins $(3,4,5,6) P_{4}$, which is in a metabolically separate pool (Menniti et al., 1990), behaved differently in the two cell types (Fig. 4D). Following purinergic activation, total Ins $(3,4,5,6) P_{4}$ levels increased more rapidly in the WT cells, and reached levels that were 55-66\% higher than those in $\mathrm{CF}$ cells throughout 90 seconds of purinergic activation $(P<0.03)$. Note that Ins $(1,4,5,6) P_{4}$, a constituent of many cells, co-elutes with Ins $(3,4,5,6) P_{4}$ upon HPLC (because the two polyphosphates are enantiomers). Stereospecific, enzymatic analysis of the $\operatorname{Ins}(3,4,5,6) P_{4}$ peak (Carew et al., 2000) revealed (data not shown) that it contained $<5 \% \operatorname{Ins}(1,4,5,6) P_{4}$.

\section{The CF condition and ITPK1 expression}

We next considered that the significance of only $\operatorname{Ins}(3,4,5,6) P_{4}$ levels being different in the two cell types, probably reflects this polyphosphate being in a discrete metabolic pool that is regulated by ITPK1 (Menniti et al., 1990). Indeed, ITPK1 is the only enzyme that can regulate cellular Ins $(3,4,5,6) P_{4}$ levels. We, therefore, investigated whether ITPKI expression is different in the two cell types.

Quantitative PCR data indicated that levels of ITPK1 RNA were approximately twofold higher in WT cells compared with CF cells (Fig. 5A). This effect was highly significant $(P<0.002)$. We were unable to reliably quantify ITPK1 protein in cell lysates by western analysis (data not shown), because our anti-human ITPK1 antibodies (Qian et al., 2005) were not sufficiently sensitive against the denatured murine protein. However, differences in ITPK1 protein levels in the two cell types were confirmed following analysis by confocal immunofluorescence microscopy (see below).

It is instructive to elaborate here about the significance of the difference of ITPK 1 expression in the two cell types. ITPK1 acts both as an $\operatorname{Ins}(3,4,5,6) P_{4}$ 1-kinase and as an Ins(1,3,4,5,6) $\mathrm{P}_{5}$ 1-phosphatase (Ho et al., 2002). The greater expression of ITPKI in the WT cells was not associated with changes in Ins $(3,4,5,6) P_{4}$ levels in the unstimulated condition (Fig. 4D), presumably because the poise of the 1-kinase / 1phosphatase cycle is not affected by increasing both catalytic activities to the same extent. However, receptor-activation specifically augments the Ins $P_{5} 1$-phosphatase activity at the expense of the Ins $(3,4,5,6) P_{4}$ 1-kinase (Ho et al., 2002). Thus, in receptor-activated cells, $\operatorname{Ins} P_{5}$ dephosphorylation to
Fig. 4. Changes in levels of Ins $(1,4,5) P_{3}$, Ins $(1,3,4,5) P_{4}$, $\operatorname{Ins}(1,3,4) P_{3}$ and $\operatorname{Ins}(3,4,5,6) P_{4}$ following purinergic activation of MTEs. WT $(\boldsymbol{\Delta})$ and CF ( MTEs were labeled for 4 days with $\left[{ }^{3} \mathrm{H}\right]$ inositol. Cells were treated with vehicle (the zero time point) or UTP (for 30, 60 or 90 seconds). Levels of the individual inositol phosphate are as indicated. (A), Ins $(1,4,5) P_{3} ;(\mathrm{B})$, Ins $(1,3,4,5) P_{4} ;(\mathrm{C})$, Ins $(1,3,4) P_{3}$; (D), Ins $(3,4,5,6) P_{4}$. Data represent mean \pm s.e.m. of five experiments. $* P<0.03 ; * * P<0.02$.
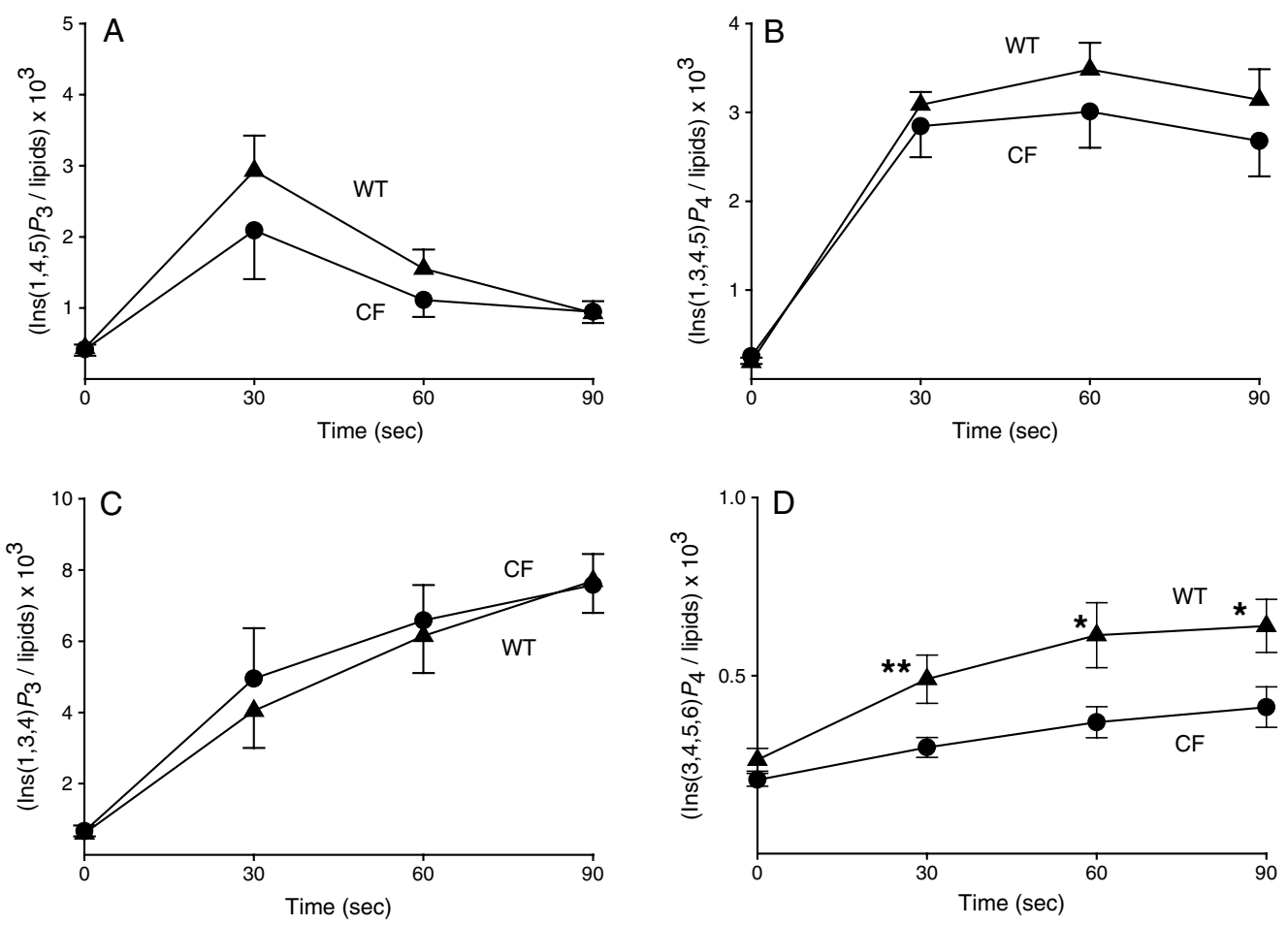

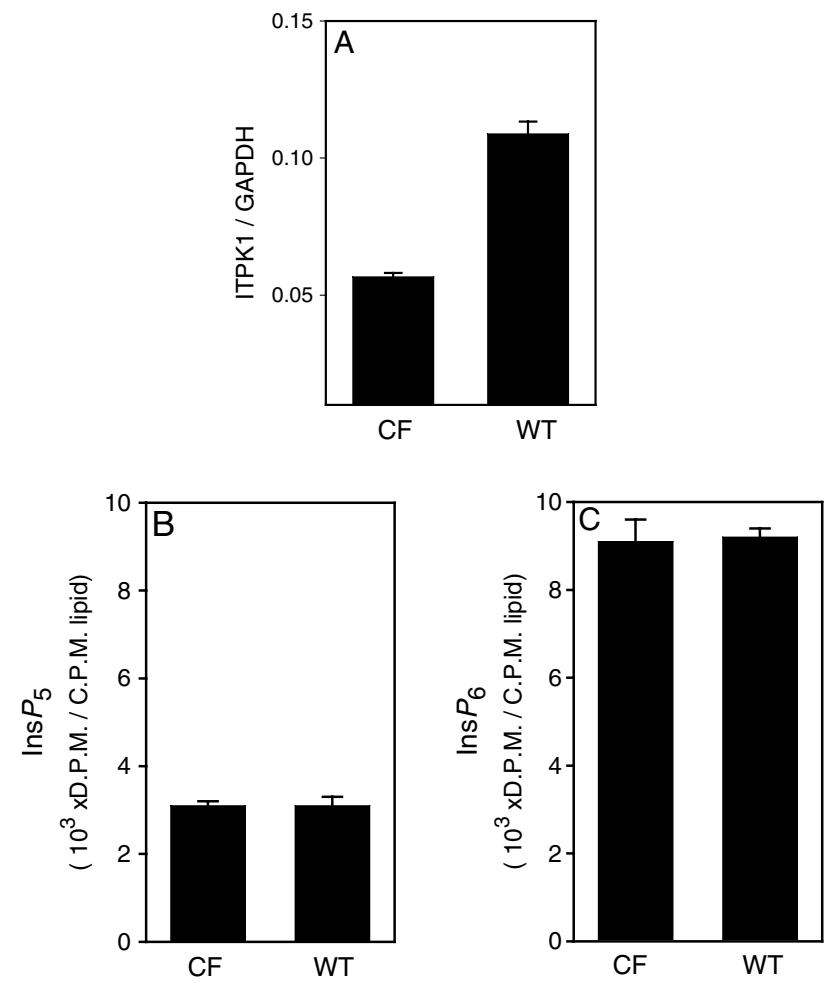

Fig. 5. Differences in ITPK1 expression in WT and CF MTEs and its impact upon synthesis of $\operatorname{Ins} P_{5}$ and $\operatorname{Ins} P_{6}$. (A-C) Quantitative PCR was used to assess the degree of ITPK1 expression in the two cell types, relative to the GAPDH control (A), as indicated in the Materials and Methods. Data represent mean \pm s.e.m. of four experiments $(P<0.002)$. Cellular levels of (B) $\operatorname{Ins} P_{5}$ and $(\mathrm{C}) \operatorname{Ins} P_{6}$ (mean \pm s.e.m. of five experiments) were determined as described in Fig. 2; levels of these two polyphosphates did not change following the addition of UTP (data not shown).
Control

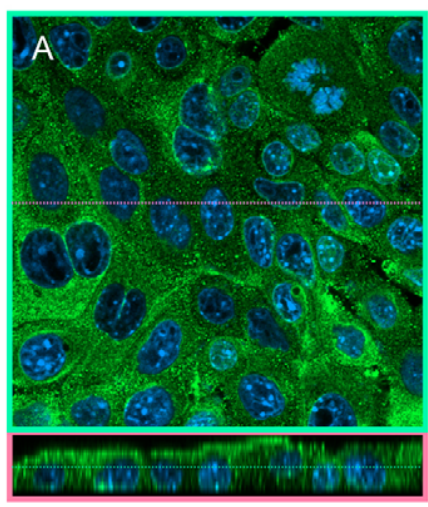

RNAi

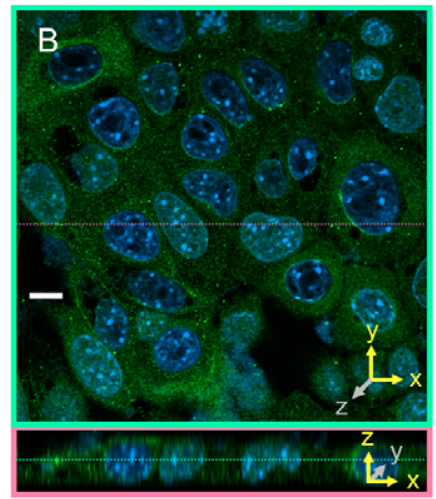

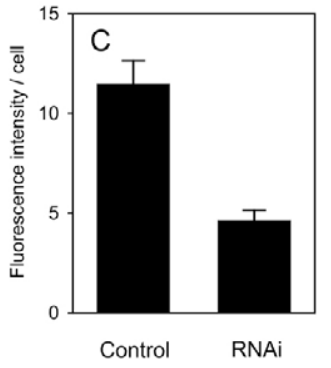

Control RNAi
Fig. 6. Analysis by confocal immunofluorescence microscopy of the decrease in ITPKI expression by RNAi in MTEs. (A,B) WT MTEs grown on glass cover slips were transfected with either control, (A) non-targeting siRNA, or (B) ITPK1-specific siRNA as described in Materials and Methods. Both horizontal $(X-Y)$ optical scanning from $Z$-stacks, and vertical $(X-Z)$ scans are shown. Dotted lines show locations of accompanying perpendicular scans. ITPK1 was visualized with Alexa Fluor 488 (green) and nuclei with DAPI (blue). Bar, 10 $\mu \mathrm{m}$. (C) Quantification of the intensity of the conjugated Alexa Fluor 488 throughout the stack volume, normalized to cell number. Data represent mean \pm s.e.m. of ten independent experiments.
Ins $(3,4,5,6) P_{4}$ can be increased by a higher degree of ITPKI expression.

ITPK1 not only regulates $\operatorname{Ins}(3,4,5,6) P_{4}$ metabolism, but through its additional ability to phosphorylate $\operatorname{Ins}(1,3,4) P_{3}$ (Yang and Shears, 2000), it also serves to provide precursor material for the synthesis of Ins $P_{5}$ and Ins $P_{6}$ (Shears, 1989; Verbsky et al., 2005). Genetic manipulation of ITPK1 levels in cultured cells - by RNA interference (RNAi) or by gene of Ins $P_{5}$ and Ins $P_{6}$ (Verbsky et al., 2005). However, the twofold (Fig. 5A) did not affect Ins $P_{5}$ and Ins $P_{6}$ levels (Fig. 5B,C). This finding offers physiological significance to small changes in ITPKI expression by virtue of it specifically controlling Ins $(3,4,5,6) P_{4}$ signaling strength during receptor activation.

\section{Intracellular distribution of ITPK1}

The early concept that soluble second messengers inevitably freely equilibrate throughout the cell has more recently been replaced by models in which there can sometimes be tight elevations in their levels within discrete subdomains (Zaccolo et al., 2002). A fundamental prerequisite of this paradigm is that the enzymes that synthesize and/or degrade the second must be restricted to a specific subcellular site qualification is met by ITPK1. For example, during its purification from tissue homogenates, the enzyme is found to be largely present in the soluble fraction (Shears, 1989; Wilson and Majerus, 1996) and has therefore been thought to be distributed throughout the cell. Furthermore, ITPK1 has no known membrane-binding or lipid-binding domains, and is not wh to be covalently modified (e.g. by myristoylation) in a manner that would facilitate its association with membranes. However, the intracellular distribution of ITPK1 has not previously been studied in intact cells.

Using non-polarized cells grown on glass coverslips, we were able to detect ITPK1 in situ by confocal immunofluorescence microscopy (Fig. 6A) using our previously described anti-ITPK1 antibodies (Qian et al., 2005). We next validated the specificity of the fluorescence signal by demonstrating that it was reduced in intensity by approximately $60 \%$, following knock-down of ITPK 1 expression by RNAi (Fig. 6).

Changes in cellular architecture during the process of cell polarization can affect the intracellular distribution of some proteins, including some that participate in inositol-phosphate signaling (Colosetti et al., 2003). When we studied the subcellular distribution of ITPK1 in polarized MTE monolayers, we found that the protein was almost entirely restricted 
to the apical pole of the cell (Fig. 7B). We also analyzed the subcellular distribution of CFTR because it is already known to be present in the apical membrane of polarized cells (Ameen et al., 2000; Bertrand and Frizzell, 2003). In the WT MTEs, the most intense CFTR signals were found at the apical periphery of the cell (Fig. 7B). CFTR and ITPK1 showed only limited colocalization, indicating that they largely occupy distinct zones of the plasma membrane (Fig. 7D). Some CFTR was also present in the lateral membranes, and some cytosolic staining was also evident (Fig. 7C). The latter is consistent with
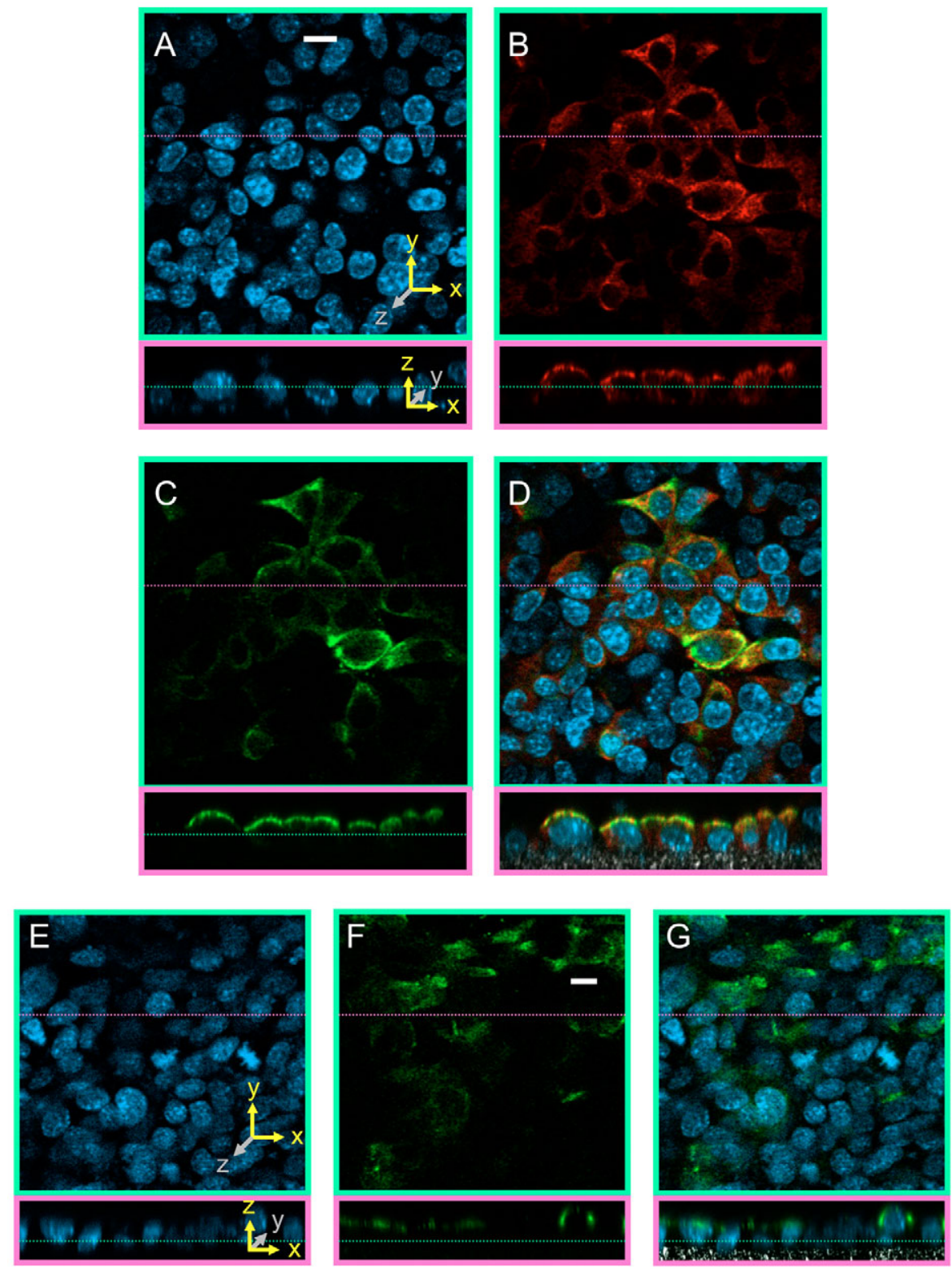

Fig. 7. Analysis by confocal immunofluorescence microscopy of ITPK1 localization in polarized MTE monolayers. Cells were grown on membrane filters and prepared for immunofluorescence confocal microscopy as described in Materials and Methods. (A-G) Cells photographed in a horizontal (X-Y) optical section, with a corresponding vertical (X-Z) optical scans; (A-D) WT cells, (E-G) CF monolayers. Nuclei were stained with DAPI (A,E; blue), CFTR was stained with Alexa Fluor 546-labeled antibody (B; red) and ITPK1 was stained with Alexa Fluor 488-labeled antibody (C,F; green). The $X-Z$ images of D and $\mathrm{G}$ include a white signal that is the confocal reflection from the filter. Bars, $10 \mu \mathrm{m}$. the idea that a subpool of CFTR resides in a vesicular 2000).

ITPK1 was also concentrated at the apical pole of the polarized CF MTEs (Fig. 7F). There was a weaker signal for TPK1 in the polarized CF MTEs (Fig. 7F) compared with the T MTEs (Fig. 7C), which is consistent with the discovery compared with the WT MTEs (see above). This difference in luorescence intensity was also observed in non-polarized cells grown on cover slips: fluorescence intensity in WT cells was $7.3 \pm 0.7$ units/cell, whereas fluorescence

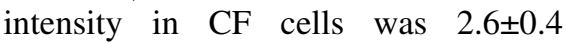
units/cell [mean \pm standard error of the mean (s.e.m.); for each cell type, the data are derived from ten fields of view, each of which contained 30-60 cells].

\section{Discussion}

In recent years, a new approach to understanding $\mathrm{CF}$ pathogenesis has emerged, which focuses on a search for so-called modifier genes that may act both to alter the severity of CF lung disease, and to affect the efficacy of therapeutic drugs (Boucher, 2004). This work largely involves complex genetic analysis (Cutting, 2005; Nagel, 2005). In the current study, we have taken an alternate, cell biological approach, and we have demonstrated that ITPKI has the necessary characteristics to be considered a candidate modifier gene.

ITPK1 synthesizes the intracellular signaling molecule Ins $(3,4,5,6) P_{4}$ (Ho et al., 2002) that, we have demonstrated, inhibits $\mathrm{Ca}^{2+}$-dependent $\mathrm{Cl}^{-}$secretion from airway epithelial cells (Fig. 1). Furthermore, we have shown that the stimulation of MTEs with purinergic agonists promotes increases in cellular levels of $\operatorname{Ins}(3,4,5,6) P_{4}$ (Fig. 3). A difference in the magnitude of the Ins $(3,4,5,6) P_{4}$ signal in WT and CF MTEs (Fig. 4) coincided with a twofold difference of ITPK1 expression in the two cell types (Fig. 5). These data provide a mechanistic explanation of the previously puzzling observation that $\mathrm{CaCC}$ activity is inherently upregulated in CF MTEs (Tarran et al., 2002). This view concerning the physiological function of ITPK differs in emphasis from that proposed by Majerus and colleagues (Verbsky et al., 2005). The latter authors concluded that pool sizes of $\operatorname{Ins} P_{5}$ and $\operatorname{Ins} P_{6}$ are regulated by ITPK1 - through the additional ability of the enzyme to phosphorylate Ins $(1,3,4) P_{3}$ (Yang and Shears, 2000). 
However, the Majerus group (Verbsky et al., 2005) came to this conclusion after they dramatically altered ITPK1 levels by either RNAi or by gene overexpression. By contrast, our data indicate that relatively small (twofold) changes in ITPK1 expression can specifically regulate $\operatorname{Ins}(3,4,5,6) P_{4}$ levels without affecting the levels of any other inositol phosphates (Figs 4, 5).

Until recently, work by Majerus and colleagues (Sun et al., 2003; Sun et al., 2002; Verbsky et al., 2005; Wilson et al., 2001) would have offered a potential complication for our hypothesis, because they proposed that ITPK1 has the ability to phosphorylate proteins as well as to metabolize inositol phosphate. However, we have recently demonstrated that the protein kinase activity in Majerus' preparations of recombinant ITPK1 was entirely due to contaminants, rather than ITPK1 itself (Qian et al., 2005). Thus, we believe that any biological differences in the two MTE cell lines that are due to ITPK1 expression are entirely mediated by the effect the enzyme has on inositol phosphate turnover.

We have also discovered an unexpected degree of structural organization to the $\operatorname{Ins}(3,4,5,6) P_{4}$ signaling system, by showing that ITPK1 is concentrated at the apical pole of the polarized cell, which is where the $\mathrm{CaCCs}$ are also located (Gabriel et al., 2000; Tarran et al., 2002). $\operatorname{Ins}(3,4,5,6) P_{4}$ synthesis, therefore, is concentrated near its site of action. Localized metabolism of Ins $(3,4,5,6) P_{4}$ can be enhanced if the architecture of the cell interior presents structural barriers that restrict the diffusion of cytosolic constituents (Rich et al., 2000). It has been suggested that such barricades form by invaginations of caveolae that protrude into the cell, or by the placement of cell organelles in close proximity to the plasma membrane (Rich et al., 2000). In the case of human airway epithelia, there is a considerable enrichment of endoplasmic reticulum and mitochondria near the apical domain (Ribeiro et al., 2003); perhaps this slows down the movement of Ins $(3,4,5,6) P_{4}$ away from the plasma membrane. It is possible that ITPK1 is compartmentalized at the apical membrane through a lipid-binding motif or by specific association with another protein that is itself membrane-bound. However, no such interaction motifs have been identified in the amino-acid sequence of ITPK1. Interestingly, we found that ITPK1 was distributed throughout the cell following its overexpression in the MTEs (data not shown). Thus, it seems likely that the mechanism responsible for directing ITPK1 to the apical pole is close to saturation just by endogenous expression levels of this enzyme.

Cell-permeant antagonists of $\operatorname{Ins}(3,4,5,6) P_{4}$ are being developed for the purpose of enhancing $\mathrm{CaCC}$ activity and thereby improving salt- and fluid-secretion in $\mathrm{CF}$ airways (Rudolf et al., 2003). Upregulation of CaCCs may have the added benefit of secondarily inhibiting $\mathrm{Na}^{+}$uptake, which further assists this approach to CF therapy (Moody et al., 2005). The degree of improvement in CaCC activity that can be elicited by $\operatorname{Ins}(3,4,5,6) P_{4}$ antagonists would be expected to be influenced by the extent to which endogenous $\operatorname{Ins}(3,4,5,6) P_{4}$ inhibits the $\mathrm{Cl}^{-}$channels, which in turn depends upon the Ins $(3,4,5,6) P_{4}$ concentration (Ho et al., 2001). Therefore, those $\mathrm{CF}$ individuals with higher levels of ITPK1 expression potentially stand to gain the most from therapy based on Ins $(3,4,5,6) P_{4}$ antagonists. Conversely, those $\mathrm{CF}$ individuals with the lower levels of ITPK1 in airway cells would synthesize less Ins $(3,4,5,6) P_{4}$ following activation of PLC; in these cells $\mathrm{CaCCs}$ would be expected to have higher activity, so these particular patients might receive greater benefit from the inhalation of purinergic agonists. We conclude that clinical trials of these candidate pharmacological approaches to $\mathrm{CF}$ should be correlated with ITPKI-expression profiling in order to detect responsive patient subgroups.

\section{Materials and Methods}

\section{Culture of mouse tracheal epithelial cell lines}

The origin of the CF and WT mouse tracheal epithelial cells (designated MTE-18 and MTE-7b, respectively) has been described previously (Thomas et al., 2000). For our experiments, CF cells were passaged 35-60 times and WT cells 40-66 times. Cells were propagated in a humidified atmosphere of $95 \%$ air and $5 \% \mathrm{CO}_{2}$ at $33^{\circ} \mathrm{C}$, in a medium consisting of a 1:1 mixture of Ham's F-12 and 3T3 fibroblastconditioned medium (Thomas et al., 2000) supplemented with transferrin (2.5 $\mu \mathrm{g} / \mathrm{ml})$, insulin $(5 \mu \mathrm{g} / \mathrm{ml})$, epidermal growth factor $(12.5 \mathrm{ng} / \mathrm{ml})$, endothelial cell growth supplement $(1.875 \mu \mathrm{g} / \mathrm{ml})$, triiodothyronine $(15 \mathrm{nM})$, hydrocortisone $(0.5$ $\mu \mathrm{M})$, and $\mathrm{CaCl}_{2}(0.5 \mathrm{mM})$.

\section{Assay of inositol phosphate turnover}

At $33^{\circ} \mathrm{C}$, MTEs were seeded on 6-well plates coated with rat-tail collagen (BD Biosciences; CA) in $1 \mathrm{ml}$ medium supplemented with $100 \mu \mathrm{Ci} / \mathrm{ml}\left[{ }^{3} \mathrm{H}\right]$ inositol (PerkinElmer Life Sciences, Boston, MA) for 4 days (medium was replaced every 2 days), at which point the cells were confluent. The culture medium was then removed and the cells were washed twice in serum-free medium. Next, $20 \mathrm{mM} \mathrm{LiCl}$ was added for an additional 20 minutes. At that point, UTP was added for various length of time, following which cells were quenched with $1 \mathrm{ml}$ of $0.6 \mathrm{M}$ ice-cold perchloric acid containing $0.2 \mathrm{mg} / \mathrm{ml} \operatorname{Ins} P_{6}$. The acid-soluble extract was neutralized with $0.31 \mathrm{ml}$ of $1 \mathrm{M} \mathrm{K}_{2} \mathrm{CO}_{3}$ containing $5 \mathrm{mM} \mathrm{Na}{ }_{2}$ EDTA. Inositol phosphates were then separated by HPLC using a $250 \times 4.6-\mathrm{mm}$ Synchropak Q100 SAX column (Thompson Instruments, Chantilly, VA) and eluted with the following gradient, generated by mixing water with buffer $\mathrm{B}\left[2 \mathrm{M}\left(\mathrm{NH}_{4}\right) \mathrm{H}_{2} \mathrm{PO}_{4} \mathrm{pH} 3.35\right.$, with $\left.\mathrm{H}_{3} \mathrm{PO}_{4}\right]$ : 0-10 minutes, $0 \%$ buffer $\mathrm{B}$; $11-124$ minutes, $0-60 \%$ buffer $\mathrm{B}$. The flow rate was 1 $\mathrm{ml} / \mathrm{minute}$. Typically, the eluate was mixed on-line with three volumes of Monoflow-4 scintillant (National Diagnostics, Atlanta, GA). $\left[{ }^{3} \mathrm{H}\right]$-labeled inositol phosphates were detected with an in-line radiometric D515 flow scintillation analyzer (FLO1; Packard Instrument Co., Meriden, CT). Levels of ${ }^{3} \mathrm{H}$-labeled inositol phosphates were analyzed by the FLO1 software and normalized against cell-lipid counts (Shears, 1997).

\section{Bioelectric studies}

MTEs were grown to confluence on transwell-COL inserts (Corning Costar, Cambridge, MA). When required, cells were harvested from culture inserts using $0.1 \%(\mathrm{w} / \mathrm{v})$ trypsin-EDTA, and reseeded at a concentration of $2 \times 10^{4}$ cells $/ \mathrm{mm}^{2}$ on snapwell inserts (Corning Costar, Cambridge, MA) coated with human placenta type VI collagen (Sigma-Aldrich). Bioelectric data were collected in Ussing chambers. Monolayers were studied 3-4 days after confluence when the membrane resistance was $>100 \Omega / \mathrm{cm}^{2}$. Once mounted in Ussing chambers, the serosal side of the monolayer was bathed in medium at $\mathrm{pH} 7.4$, containing $0.4 \mathrm{mM} \mathrm{KH}_{2} \mathrm{PO}_{4}, 2.4$

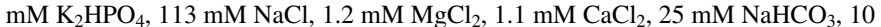
$\mathrm{mM}$ glucose. The mucosal medium (also $\mathrm{pH}$ 7.4) contained $0.4 \mathrm{mM} \mathrm{KH}_{2} \mathrm{PO}_{4}, 2.4$ $\mathrm{mM} \mathrm{K}_{2} \mathrm{HPO}_{4}, 15 \mathrm{mM}$ Na-gluconate, $95 \mathrm{mM}$ K-gluconate, $1.2 \mathrm{mM} \mathrm{MgCl}_{2}, 1.1 \mathrm{mM}$ $\mathrm{CaCl}_{2}, 25 \mathrm{mM} \mathrm{NaHCO}_{3}, 10 \mathrm{mM}$ glucose. The Ussing solutions were maintained at $33^{\circ} \mathrm{C}$ and gassed with a mixuture $95 \% \quad \mathrm{O}_{2}$ and $5 \% \quad \mathrm{CO}_{2}$. Where indicated, $\mathrm{Bt}_{2} \mathrm{Ins}(3,4,5,6) P_{4} / \mathrm{PM}$ and $\mathrm{Bt}_{2} \operatorname{Ins}(1,4,5,6) P_{4} / \mathrm{PM}$ (SiChem, Bremen, Germany) were added from stock solutions prepared in dried DMSO containing $5 \%(\mathrm{v} / \mathrm{v})$ pluronic F-127. The epithelial monolayers were continuously voltage-clamped (i.e. shortcircuited) to a transepithelial potential difference of zero. The magnitude and the polarity of the applied short-circuit current $\left(\mathrm{I}_{\mathrm{SC}}\right)$ is a measure of the extent and direction of the electrogenic ion flux across the epithelial layer. $\mathrm{I}_{\mathrm{SC}}$ was recorded every 0.5 seconds, with a PowerLab/800 interface (AD Instruments Inc., Milford, $\mathrm{MA}$ ) on a PC running Chart v3.4. ASCII data for each trace were exported to SigmaPlot (v8), whereupon the $\mathrm{I}_{\mathrm{SC}}$ value was set to zero at the time UTP was added to the monolayers.

\section{RNA interference}

ITPK1 was depleted with siRNA oligonucleotide mixture (siGENOME SMARTpool: Dharmacon, Inc. Lafayette, CO), the design of which was based on the mouse ITPK1 sequence (GenBank accession number AK038913). siRNA oligonucleotide sequences were verified by RT-PCR of cDNA obtained from WT MTEs, using the following primers to amplify the entire coding region: $5^{\prime}-$ GAATTCCATGCAGACCTTCCTGAAAGGGAAG-3' and '5'-AGATCTCTA CTGTGAGGAAGCCTTGGTGGCC-3'. The ITPK1-specific siRNA (100 nM) and control siRNA (siCONTROL non-targeting siRNA pool from Dharmacon, Inc.) 
were transfected into WT MTEs with Lipofectamine 2000 (Life Technologies). Transfected cells were analyzed 60 hours after transfection.

\section{Quantitative PCR}

RNA was prepared from confluent CF and WT MTEs using the RNeasy Mini Kit (Qiagen Inc., CA); $5 \mu \mathrm{g}$ of total RNA was used for each reverse transcription of cDNA, and $3 \mu \mathrm{l}$ of 1:5 diluted cDNA was used as a PCR-amplification template. All reactions were performed using Sybr Green Master Mix (Applied Biosystems, CA). PCR was carried out with the ABI PRISM 7900HT Sequence Detection System (Applied Biosystems, CA). Amplification conditions and calibration curves are as described previously (Deleu et al., 2006). The mouse GAPDH gene was chosen as an internal control for quantitative PCR. These primer sequences were: 5'-GCAAAGTGGAGATTGTTGCCAT-3' and 5'-CCTTGACTGTGCCGTTGAATTT-3'. ITPK1 primer sequences were as follows: $5^{\prime}$-CAGAGTGGCTCATGGAACCAA-3'; 5'-CAGGACAGCATTGTGGTTGATG-3' .

\section{Confocal immunofluorescence microscopy.}

MTEs were grown to confluence on Transwell-Col culture chambers with a diameter of $12 \mathrm{~mm}$. After 48 hours of incubation, cells were washed with Dulbecco's phosphate buffered saline (DPBS, without $\mathrm{Ca}^{2+}$ and $\mathrm{Mg}^{2+}$ ) and fixed in 3\% paraformaldehye in $25 \mathrm{mM}$ HEPES, $10 \mathrm{mM}$ EGTA, $60 \mathrm{mM}$ PIPES, $4 \mathrm{mM}$ $\mathrm{MgSO} 4$, (pH 7.0) for 20 minutes at $4^{\circ} \mathrm{C}$. After several washes in DPBS, cells were permeablized by $1 \%$ Triton X-100 in DPBS for 5 minutes at room temperature, then incubated in PBS containing 1\% BSA for 20-30 minutes at room temperature. For the studies shown herein, cells were either incubated in PBS containing 1\% BSA and either a 1:500 dilution of affinity-purified rabbit anti-human ITPK1 antibody (Qian et al., 2005) or a 1:200 dilution of CFTR mouse monoclonal antibody (NeoMarkers, Fremont, CA) for 2 hours at room temperature. Thereafter, the cells were washed and incubated 1 hour in PBS with $1 \%$ BSA containing Alexa-Fluor-488-conjugated or Alexa-Fluor-546-conjugated secondary antibodies (Invitrogen, Carlsbad, CA) to visualize ITPK1 or CFTR, respectively. Cells were then washed and incubated with 4,6-diamidino-2phenylindole, dilactate (DAPI, 1:15,000 dilution) (Sigma, St Louis, MO) for 10 minutes. The fixed cells on chambers were then mounted in PBS buffer. A laser scanning confocal microscope with two-photon excitation option (LSM 510 NLO mounted on Axiovert 100M microscope, Carl Zeiss, Inc.) was used to obtain XY and XZ fluorescence images. The objective lenses used were the C-Apochromat $40 \times / 1.2$ water immersion for membrane insert imaging in $X Y$ and $X Z$ mode, and the Plan-Apo $63 \times$ oil immersion NA 1.4 for $Z$-stack imaging of cells grown on cover glass. Images from different probes were obtained sequentially to maximize fluorescence detection. For the Alexa Fluor probes, the $488 \mathrm{~nm} \mathrm{Ar}$ laser and the $543 \mathrm{~nm} \mathrm{HeNe}$-laser were used for excitation, and the emission filters were BP500-550 and LP560 for the green and red probes, respectively. For DAPI, two-photon excitation was achieved with the Verdi-Mira laser (Coherent Laser, Carlsbad, CA) tuned to $750 \mathrm{~nm}$, and the emission filter was BP435-485. The pinholes used for confocal imaging were set to $\sim 1$ Airy Unit to approximately match the $Z$-resolution of two-photon excitation, i.e. $\sim 0.9 \mu \mathrm{m}$ for the $40 \times$ water lens (membrane imaging), and $\sim 0.7 \mu \mathrm{m}$ for the $63 \times$ oil lens (coverglass imaging). For each $Z$-stack, ten image slices were acquired at regular intervals of $1.9 \mu \mathrm{m}$ in $Z$, to sample the total thickness of the cells, which was no more than $15 \mu \mathrm{m}$. For quantitation of ITPK1 expression per cell from Z-stacks, a ratio was performed of the background-subtracted, average pixel intensity of the conjugated Alexa Fluor 488 throughout the stack volume, to the number of cells visually apparent from a rotating projection of the corresponding DAPI-stained (nuclei) Z-stack. Membrane images used for the figures have been digitally smoothed with a $3 \times 3$ filter. Contrast enhancement was performed separately on all images shown, so that they all have approximately the same background and the same level of saturation. The software used for processing and analysis was Zeiss LSM Image Examiner (licensed) version 3.2.

We thank Tarra Wasilchen for technical assistance. S.E.G. is supported by awards NIH HL 62564 and CFF GABRIE04G2. This research was also supported by the Intramural Research Program of the NIH, National Institute of Environmental Health Sciences.

\section{References}

Ameen, N. A., van Donselaar, E., Posthuma, G., de Jonge, H., McLaughlin, G., Geuze, H. J., Marino, C. and Peters, P. J. (2000). Subcellular distribution of CFTR in rat intestine supports a physiologic role for CFTR regulation by vesicle traffic. Histochem. Cell Biol. 114, 219-228.

Berridge, M. J., Lipp, P. and Bootman, M. D. (2000). The versatility and universality of calcium signalling. Nat. Rev. Mol. Cell. Biol. 1, 11-21.

Bertrand, C. A. and Frizzell, R. A. (2003). The role of regulated CFTR trafficking in epithelial secretion. Am. J. Physiol. Cell Physiol. 285, C1-C18.

Boucher, R. C. (2004). New concepts of the pathogenesis of cystic fibrosis lung disease. Eur. Respir. J. 23, 146-158.

Carew, M. A., Yang, X., Schultz, C. and Shears, S. B. (2000). Ins $(3,4,5,6) \mathrm{P}_{4}$ inhibits an apical calcium-activated chloride conductance in polarized monolayers of a cystic fibrosis cell-line. J. Biol. Chem. 275, 26906-26913.

Chan, H. C., Goldstein, J. and Nelson, D. J. (1992). Alternative pathways for chloride activation in normal and cystic fibrosis airway epithelial cells. Am. J. Physiol. 262, C1273-C1283.

Chao, A. C., Zifferblatt, J. B., Wagner, J. A., Dong, Y.-J., Gruenert, D. C. and Gardner, P. (1994). Stimulation of chloride secretion by P1 purinergic agonists in cystic fibrosis phenotype airway epithelial cell line CFPEo-. Br. J. Pharmacol. 112, $169-175$.

Clarke, L. L., Grubb, B. R., Yankaskas, J. R., Cotton, C. U., McKenzie, A. and Boucher, R. C. (1994). Relationship of a non-cystic fibrosis transmemebrane conductance regulator-medaited chloride conductance to organ level disease in Cftr(-/-) mice. Proc. Natl. Acad. Sci. USA 91, 479-483.

Colosetti, P., Tunwell, R. E., Cruttwell, C., Arsanto, J. P., Mauger, J. P. and Cassio, D. (2003). The type 3 inositol 1,4,5-trisphosphate receptor is concentrated at the tight junction level in polarized MDCK cells. J. Cell Sci. 116, 2791-2803.

Cutting, G. R. (2005). Modifier genetics: cystic fibrosis. Апnи. Rev. Genomics Hum. Genet. 6, 237-260.

Deleu, S., Choi, K., Pesesse, X., Cho, J., Sulis, M. L., Parsons, R. and Shears, S. B. (2006). Physiological levels of PTEN control the size of the cellular Ins(1,3,4,5,6)P5 pool. Cell Signal. 18, 488-498.

Deterding, R., Retsch-Bogart, G., Milgram, L., Gibson, R., Daines, C., Zeitlin, P. L., Milla, C., Marshall, B., Lavange, L., Engels, J., Mathews, D., Gorden, J., Schaberg, A., Williams, J. and Ramsey, B. (2005). Safety and tolerability of denufosol tetrasodium inhalation solution, a novel P2Y2 receptor agonist: results of a phase 1/phase 2 multicenter study in mild to moderate cystic fibrosis. Pediatr. Pulmonol. 39, 339-348.

Fuller, C. M., Ismailov, I. I., Keeton, D. A. and Benos, D. J. (1994). Phosphorylation and activation of a bovine tracheal anion channel by $\mathrm{Ca} 2+/$ calmodulin-dependent protein kinaseII. J. Biol. Chem. 269, 26642-26650.

Gabriel, S. E., Makhlina, M., Martsen, E., Thomas, E. J., Lethem, M. I. and Boucher, R. C. (2000). Permeabilization via the P2X7purinoreceptor reveals the presence of a $\mathrm{Ca} 2+$-activated $\mathrm{Cl}^{-}$conductance in the apical membrane of murine tracheal epithelial cells. J. Biol. Chem. 275, 35028-35033.

Grubb, B. R., Vick, R. N. and Boucher, R. C. (1994). Hyperabsorption of Na+ and raised $\mathrm{Ca} 2+-$ mediated $\mathrm{Cl}^{-}$secretion in nasal epithelia of CF mice. Am. J. Physiol. 266, c1478-c1483.

Heijerman, H. (2005). Infection and inflammation in cystic fibrosis: A short review. $J$. Cyst. Fibros. 4, S3-S5.

Ho, M. W. Y. and Shears, S. B. (2002). Regulation of calcium-activated chloride channels by inositol 3,4,5,6-tetrakisphosphate. In Current Topics in Membranes 53 (ed. C. M. Fuller), pp. 345-363. London: Academic Press.

Ho, M. W. Y., Kaetzel, M. A., Armstrong, D. L. and Shears, S. B. (2001). Regulation of a human chloride channel: A paradigm for integrating input from calcium, CaMKII and $\operatorname{Ins}(3,4,5,6) \mathrm{P}_{4}$. J. Biol. Chem. 276, 18673-18680.

Ho, M. Y. H., Yang, X., Carew, M. A., Zhang, T., Hua, L., Kwon, Y.-U., Chung, S.K., Adelt, S., Vogel, G., Riley, A. M., Potter, B. V. L. and Shears, S. B. (2002). Regulation of Ins(3456)P4 signaling by a reversible kinase/phosphatase. Curr. Biol. 12, $477-482$.

Irvine, R. F. (1991). Inositol tetrakisphosphate as a second messenger: confusions, contradictions and a potential resolution. BioEssays 13, 419-427.

Ismailov, I. I., Fuller, C. M., Berdiev, B. K., Shlyonsky, V. G., Benos, D. J. and Barrett, K. E. (1996). A biologic function for an "orphan" messenger: D-myo-Inositol 3,4,5,6tetrakisphosphate selectively blocks epithelial calcium-activated chloride current. Proc. Natl. Acad. Sci. USA 93, 10505-10509.

Jentsch, T. J., Stein, V., Weinreich, F. and Zdebik, A. A. (2002). Molecular structure and physiological function of chloride channels. Physiol. Rev. 82, 503-568.

Kidd, J. F. and Thorn, P. (2000). Intracellular $\mathrm{Ca}^{2+}$ and $\mathrm{Cl}^{-}$channel activation in secretory cells. Аnпи. Rev. Physiol. 62, 493-513.

Lazarowski, E. R. and Boucher, R. C. (2001). UTP as an extracellular signaling molecule. News Physiol. Sci. 16, 1-5.

Loewen, M. E. and Forsyth, G. W. (2005). Structure and Function of CLCA Proteins. Physiol. Rev. 85, 1061-1092.

Mall, M., Gonska, T., Thomas, J., Schreiber, R., Seydewitz, H. H., Kuehr, J., Brandis, M. and Kunzelmann, K. (2003). Modulation of $\mathrm{Ca} 2+$-activated $\mathrm{Cl}^{-}$secretion by basolateral $\mathrm{K}+$ channels in human normal and cystic fibrosis airway epithelia. Pediatr. Res. 53, 608-618.

Menniti, F. S., Oliver, K. G., Nogimori, K., Obie, J. F., Shears, S. B. and Putney, J. W., Jr (1990). Origins of myo-inositol tetrakisphosphates in agonist-stimulated rat pancreatoma cells. Stimulation by bombesin of myo-inositol $(1,3,4,5,6)$ pentakisphosphate breakdown to myo-inositol $(3,4,5,6)$ tetrakisphosphate. J. Biol. Chem. 265, 11167-11176.

Merlo, C. A. and Boyle, M. P. (2003). Modifier genes in cystic fibrosis lung disease. J. Lab. Clin. Med. 141, 237-241.

Moody, M., Pennington, C., Schultz, C., Caldwell, R., Dinkel, C., Rossi, M. W., McNamara, S., Widdicombe, J., Gabriel, S. and Traynor-Kaplan, A. E. (2005). An inositol polyphosphate derivative inhibits $\mathrm{Na}$ + flux and improves fluid dynamics in cystic fibrosis airway epithelia. Am. J. Physiol. Cell Physiol. 289, C512-C520.

Nagel, R. L. (2005). Epistasis and the genetics of human diseases. C. R. Biol. 328, 606615.

Paradiso, A. M., Ribeiro, C. M. P. and Boucher, R. C. (2001). Polarized signaling via purinoceptors in normal and cystic fibrosis airway epithelia. J. Gen. Physiol. 117, 5367. 
Qian, X., Mitchell, J., Wei, S. J., Williams, J., Petrovich, R. M. and Shears, S. B. (2005). The Ins $(1,3,4) \mathrm{P} 35 / 6$-kinase / Ins $(3,4,5,6) \mathrm{P} 4$ 1-kinase is not a protein kinase. Biochem. J. 2005, 389-395.

Ribeiro, C. M., Paradiso, A. M., Livraghi, A. and Boucher, R. C. (2003). The mitochondrial barriers segregate agonist-induced calcium-dependent functions in human airway epithelia. J. Gen. Physiol. 122, 377-387.

Ribeiro, C. M., Paradiso, A. M., Carew, M. A., Shears, S. B. and Boucher, R. C. (2005). Cystic fibrosis airway epithelial $\mathrm{Ca} 2+\mathrm{i}$ signaling: the mechanism for the larger agonist-mediated $\mathrm{Ca} 2+\mathrm{i}$ signals in human cystic fibrosis airway epithelia. J. Biol. Chem. 280, 10202-10209.

Rich, T. C., Fagan, K. A., Nakata, H., Schaack, J., Cooper, D. M. and Karpen, J. W. (2000). Cyclic nucleotide-gated channels colocalize with adenylyl cyclase in regions of restricted cAMP diffusion. J. Gen. Physiol. 116, 147-161.

Rudolf, M. T., Dinkel, C., Traynor-Kaplan, A. E. and Schultz, C. (2003). Antagonists of myo-inositol 3,4,5,6-tetrakisphosphate allow repeated epithelial chloride secretion. Bioorgan. Med. Chem. 11, 3315-3329.

Sasakawa, N., Ferguson, J. E., Sharif, M., and Hanley, M. R. (1994). Attenuation of agonist-induced desensitization of the rat substance $\mathrm{P}$ receptor by microinjection of inositol pentakis- and hexakisphosphates in Xenopus laevis oocytes. Mol. Pharmacol. 46, 380-385.

Shears, S. B. (1989). The pathway of myo-inositol 1,3,4-trisphosphate phosphorylation in liver. Identification of myo-inositol 1,3,4-trisphosphate 6-kinase, myo-inositol 1,3,4trisphosphate 5-kinase, and myo-inositol 1,3,4,6-tetrakisphosphate 5-kinase. J. Biol. Chem. 264, 19879-19886.

Shears, S. B. (1997). Measurement of inositol phosphate turnover in intact cells and cellfree systems. In Signalling by Inositides: A Practical Approach (ed. S. B. Shears), pp. 33-52. Oxford: Oxford University Press.

Stoughton, R. B. and Friend, S. H. (2005). How molecular profiling could revolutionize drug discovery. Nat. Rev. Drug Discov. 4, 345-350.

Sun, Y., Wilson, M. P. and Majerus, P. W. (2002). Inositol 1,3,4-trisphosphate 5/6kinase associates with the COP9 signalosome by binding to CSN1. J. Biol. Chem. 277, 45759-45764

Sun, Y., Mochizuki, Y. and Majerus, P. W. (2003). Inositol 1,3,4-trisphosphate 5/6kinase inhibits tumor necrosis factor-induced apoptosis. J. Biol. Chem. 278, 4364543653.
Tarran, R., Loewen, M. E., Paradiso, A. M., Olsen, J. C., Gray, M. A., Argent, B. E., Boucher, R. C. and Gabriel, S. E. (2002). Regulation of murine airway surface liquid volume by CFTR and $\mathrm{Ca}^{2+}$-activated $\mathrm{Cl}^{-}$conductances. J. Gen. Physiol. 120, 407-418.

Tarran, R., Button, B., Picher, M., Paradiso, A. M., Ribeiro, C. M., Lazarowski, E. R., Zhang, L., Collins, P. L., Pickles, R. J., Fredberg, J. J. and Boucher, R. C. (2005). Normal and cystic fibrosis airway surface liquid homeostasis: The effects of phasic shear stress and viral infections. J. Biol. Chem. 280, 35751-35759.

Thomas, E. J., Gabriel, S. E., Makhlina, M., Hardy, S. P. and Lethem, M. I. (2000). Expression of nucleotide-regulated $\mathrm{Cl}^{-}$currents in $\mathrm{CF}$ and normal mouse tracheal epithelial cell lines. Am. J. Physiol. 279, C1578-C1586.

Vajanaphanich, M., Schultz, C., Rudolf, M. T., Wasserman, M., Enyedi, P., Craxton, A., Shears, S. B., Tsien, R. Y., Barrett, K. E. and Traynor-Kaplan, A. E. (1994). Long-term uncoupling of chloride secretion from intracellular calcium levels by Ins $(3,4,5,6) \mathrm{P}_{4}$. Nature 371, 711-714.

Verbsky, J. W., Chang, S. C., Wilson, M. P., Mochizuki, Y. and Majerus, P. W. (2005). The pathway for the production of inositol hexakisphosphate in human cells. J. Biol. Chem. 280, 1911-1920.

Wagner, J. A., McDonald, T. V., Nghiem, P. T., Lowe, A. W., Schulman, H., Gruenert, D. C., Stryer, L. and Gardner, P. (1992). Antisense oligodeoxy neucleotides to the cystic fibrosis regulator inhibit cAMP-activated but not calcium activated chloride currents. Proc. Natl. Acad. Sci. USA 89, 6785-6789.

Wilson, M. P. and Majerus, P. W. (1996). Isolation of inositol 1,3,4-trisphosphate 5/6kinase, cDNA cloning, and expression of recombinant enzyme. J. Biol. Chem. 271, 11904-11910.

Wilson, M. P., Sun, Y., Cao, L. and Majerus, P. W. (2001). Inositol 1,3,4-trisphosphate 5/6-kinase is a protein kinase that phosphorylates the transcription factors c-jun and ATF-2. J. Biol. Chem. 276, 40998-41004.

Xie, W., Kaetzel, M. A., Bruzik, K. S., Dedman, J. R., Shears, S. B. and Nelson, D. J. (1996). Inositol 3,4,5,6-tetrakisphosphate inhibits the calmodulin-dependent protein kinase II-activated chloride conductance inT84 colonic epithelial cells. J. Biol. Chem. 271, 14092-14097.

Yang, X. and Shears, S. B. (2000). Multitasking in signal transduction by a promiscuous human Ins(3,4,5,6)P4 1-kinase/Ins(1,3,4)P3 5/6-kinase. Biochem. J. 351, 551-555.

Zaccolo, M., Magalhães, P. and Pozzan, T. (2002). Compartmentalization of cAMP and $\mathrm{Ca}^{2+}$ signals. Curr. Opin. Cell Biol. 14, 160-166. 